\title{
Analysis of Students' Knowledge About Natural Disaster Mitigation in Wetland Areas
}

\author{
Muhsinah Annisa $^{(1)^{*}}$, Asrani Asrani $^{(2)}$, Serlinda Serlinda ${ }^{(3)}$, Simpai Kasih $^{(4)}$, Sayyidil Maulana(5)
}

$(1,2,3,4,5)$ Lambung Mangkurat University, Indonesia

*Correspondence to: muhsinah.annisa@ulm.ac.id

\begin{abstract}
Indonesia has high potential disasters. It was recorded that more than 1,800 disasters occurred in 2005-2015, of which $78 \%$ of the disasters were hydrometeorological (floods, landslides, drought, forest, and land fires). Previous research also stated that the West Kalimantan region has several threats of disasters, such as the threat of floods, landslides, forest fires, which are scattered with a percentage of the area of $82.96 \%$. This study explores students' initial knowledge about their understanding of disaster mitigation in the Kalimantan area. This research is essential because there is no single research data that shows the condition of students' prior knowledge of disaster mitigation in Kalimantan. This research uses a quantitative descriptive approach. Samples were taken using the purposive sampling technique. Data were collected by observation and questionnaires. Data analysis techniques using percentages. Overall, the level of students' knowledge regarding natural disaster mitigation in wetlands was in the moderate category, namely $44.85 \%$. Understanding natural disaster mitigation includes learning, emergency response planning, disaster warning, and resource mobilization. The government alone cannot take all mitigation measures in society. Therefore, disaster education is limited to school students and must also be promoted to families and communities, which is very important for elaborating mitigation knowledge.
\end{abstract}

Keywords: mitigation; natural disasters; student knowledge; wetland areas

Recommended citation: Annisa, M., Asrani, A., Serlinda, S., Kasih, S., \& Maulana, S. (2022). Analysis of Students' Knowledge About Natural Disaster Mitigation in Wetland Areas. Journal of Innovation in Educational and Cultural Research, 3(1), 12-19.

\section{INTRODUCTION}

Every year, natural disasters such as landslides, earthquakes, floods, wind and ice storms, droughts, volcanic eruptions, and tsunamis worldwide cause more than 318 natural disasters nationwide that killed almost 9,503 peoples and affected more than 96 million peoples (CRED, 2017). The disaster situation at the local level is even worse. BNPB reports that data shows Indonesia as one of the countries with the highest earthquake rate globally, ten times higher than the earthquake in the United States (BNPB, 2021). Natural disasters, earthquakes, tsunamis, cyclones, typhoons, and hurricanes are the deadliest and most expensive and are also responsible for the enormous annual loss of life and property in the world. Every time a disaster occurs, many school children became victims, and many of them never return; For example, in 1988, the Spitak Earthquake (Armenia) killed more than 17,000 students while in school, which is $2 / 3$ of the total death toll from the earthquake; Likewise in 2001, 971 students and 31 teachers died in the Bhuj earthquake in India; In 2004, fire tragedy caused by a cooking gas cylinder explosion in Tamil Nadu (India) killed 93 school children; The most terrible disasters at schools were recorded in 2005 after the Kashmir (northern Pakistan) Earthquake, which killed 17,000 students in various schools while another 50,000 were seriously injured; In 2006, an elementary school in the Philippines was buried in a landslide, and 245 children and teachers were killed; What's more, in 2008, more than 10,000 children died during the Sichuan Earthquake in China (Tuladhar, 2013).

The potential for disasters in Indonesia is also high. It is recorded that there have been more than 1,800 disasters in $2005-2015$, of which $78 \%$ of the tragedies that have occurred were hydrometeorological (floods, landslides, drought, forest and land fires, tidal waves) and $22 \%$ of geological disasters. Many disaster events could cause loss of knowledge assets, accounting for 12 million US dollars per year for re-working lost information. In general, the disaster trends in Indonesia increased from 2002 - 2014 (Kurniawan, 2019). The potential for a tsunami disaster in Indonesia is ranked first out of 265 countries globally. Even the risk of a tsunami threat in Indonesia is higher than in Japan, affecting 5,402,239 people (BNPB, 2021). Based on previous research in parts of West Kalimantan regarding disaster analysis based on events and physical hazard analysis, it was found that the area had several disaster threats such as the threat of floods, 
landslides, tornadoes, forest fires, and residential fires with moderate levels of vulnerability with percentage area of $82.96 \%$. The rest areas are a low level of exposure, as much as $10.15 \%$, with a high level of vulnerability as much as $6.88 \%$. (Wahyuningtyas, 2015). The latest fact was that the floods in South Kalimantan resulted in 21,990 people submerging 6,346 houses (Jati, 2021), and the flood that occurred in 2021 was the first flood since 92 years ago. School-related world disaster data and past disasters show that school children are also at extreme risk of natural disasters, especially when they are supposed to be in school. Disasters not only threaten the lives of children but also have an impact on education, the economy, and children's psychology, and their families. When disasters hit schools, children's hard-earned educational rights are always disturbed. In addition, most of the time is lost after the disaster resulting in irreparable deterioration in the quality of education. Sometimes, some children cannot even continue their education, resulting in permanent dropouts. The former lack of resilience and empowerment can tear down the deliverable and established systems of the school community. This effect was well observed after the 1988 Udaypur Earthquake and the Sikkim-Nepal Earthquake on September 18, 2011 (Tuladhar, 2013).

The research findings previously revealed that the symptoms of post-traumatic stress in school students were usually moderate to severe. Therefore, disaster risk reduction (DRR) education for school students and teachers is crucial to building teachers 'and students' understanding of the causes, nature, and impacts of natural disasters. It also cultivates a range of competencies and skills to enable teachers and students to contribute proactively to disaster prevention and mitigation. Many studies have also examined that the effect of student participation in disaster education programs is always promising, and the results are very effective (Ronan et al., 2010). Likewise, school-based disaster education programs help improving community disaster preparedness (Rahma, 2018).

Problems related to mitigation are significant, especially for school-age children, because of the large number of fatalities that come from school-age children (Tuladhar, 2014). However, in previous studies, the discussion focused a lot on mitigation learning (Wedyawati, 2017), learning models with an orientation on mitigation (Jairina, 2020), the impact and influence of disasters on land (Rosyidie, 2013), some also discussed ecosystem management as mitigation in South Kalimantan (Sudrajat, 2019), the use of clustering algorithms for natural disaster mitigation (Sadewo, 2018), (Salminah, 2019), strategies for dealing with climate mitigation problems (Nyong, 2007; Surahman, 2018; Lounela, 2020), the role of the village team's facility approach in mitigation in South Kalimantan (Arai, 2021), ease of changes in oil palm land (Van der Laan, 2017; Austin, 2015), some even mention that mitigation strategies need to include wetlands (Murdiyarso et al., 2014), mitigation options on N. emissions2O from corn fields in Kalimantan (Hadi et al., 2010) and no one has discussed mitigation knowledge on students in the wetlands of South Kalimantan.

The discrepancy between the facts on the ground and previous research needs to be addressed immediately. This is done to create more conducive and safe conditions when disasters occur in Indonesia, especially in South Kalimantan. In this context, this research aims to explore students' initial knowledge about their understanding of disaster mitigation in the Kalimantan area, namely mitigation-related educational programs. More specifically, it examines aspects of initial knowledge of mitigation among school children. Although many studies discuss mitigation in Indonesia generally and Kalimantan mainly, there is no single research data that shows the condition of students' initial knowledge of mitigation. disaster in Kalimantan. Therefore, this research is fundamental as the initial information obtained to be used for further research to be targeted directly at the areas in need.

\section{METHOD}

This research is a form of initial investigation which is included in survey research. The analytical approach used to describe the conditions in the field uses a quantitative descriptive approach, where what is done is to describe the value of the percentage results of students' mitigation knowledge findings in the field. This study was conducted to describe students' initial knowledge about natural disaster mitigation commonly occurring in wetland areas, namely floods, forest fires, landslides. The time of the study was carried out from January to May 2021. The sampling technique used purposive sampling, deliberately taking respondents in the wetland area for high-grade elementary school children. Data collection techniques were carried out by conducting observations, questionnaires, and interviews. 


\section{Sample}

The number of samples in this study was 121 elementary school high school students with $40.3 \%$ of 4th graders, $40.3 \%$ of 5 th graders, and $40.3 \%$ of 6th graders, with grade 6 . Thus, the age range of the respondents is 8 to 12 years old who come from 8 elementary schools in the Wetlands area in South Kalimantan.

\section{Instrument}

The instrument in this study was a semi-open questionnaire. There are 38 questions used to find out students' knowledge about natural disaster mitigation in wetland areas. The survey criteria used in this study were made in one survey, which was divided into four parameters that refer to previous research conducted (Tuladhar, 2014) in Nepal.

Knowledge. The questions asked to discuss disaster experiences. Respondents were asked to indicate whether they had experienced disaster in their life and any terrible tragedy they experienced or were aware of. Emergency response planning. The questions posed are used to find out information on the respondent's readiness. Questionnaires about various natural disasters were used to assess respondents' knowledge and the best course of action they would take in the event of a disaster. Questions related to their understanding of three types of disasters that often occur in South Kalimantan (namely floods, landslides, forest fires) were asked where the answers used were yes / no format accompanied by reasons. For various types of disasters, students are also invited to show what behaviors or behaviors they would support in a particular disaster event according to the disaster education they receive in their schools, if any. Disaster warning. The questions posed serve to find out the respondent's knowledge regarding several disaster warning methods that are often used in the wetlands of South Kalimantan. Mobilization of resources. The questions posed are used to determine disaster awareness, adaptation, and risk perception. Respondents were given about 14 questions that discussed their knowledge of some issues related to disasters and some knowledge about disaster mitigation that occurred related to the factors of resources in the surrounding area to local wisdom owned and government efforts.

\section{Data Collection}

Collecting data is through non-test, namely by giving questionnaires to students, interviews, and observations in the school environment. In the questionnaire, questions were presented with answer choices indicating that respondents knew about mitigation or did not know about relief and several disasters in wetlands, namely around floods, forest fires, and landslides. The question column is also accompanied by essay answers to answer questions in the questionnaire to get a picture following the facts on the ground. In addition, interviews with teachers were also conducted to validate/strengthen the data obtained from students' knowledge of natural disaster mitigation in wetland areas.

\section{Analyzing Data}

The percentage used in this study was obtained from the calculation of the total number of correct answers, then divided by the total number of all incoming solutions. Then the results were multiplied by one hundred percent. This is done for each analysis point described in the discussion section. The results of the percentage gain are then analyzed about the scores represented in the Table 1.

Table 1. Categories of Students' Knowledge Levels
\begin{tabular}{cc} 
Knowledge level & Category \\
\hline $76 \%-100 \%$ & Very well \\
$56 \%-75 \%$ & Good \\
$40 \%-55 \%$ & Enough \\
$40 \%-55 \%$ & Less \\
$<40 \%$ & Failed \\
\hline
\end{tabular}




\section{RESULT AND DISCUSSION}

\section{Result}

Overall, the level of students' knowledge regarding natural disaster mitigation in wetlands was in a suitable category, namely $44.85 \%$. Understanding natural disaster mitigation includes the first aspect, namely the knowledge aspect, the second aspect, namely emergency response planning; the third aspect, namely disaster warning; and the fourth stage, namely the mobilization of resources. Student knowledge data is presented in Figure 1, and the details are shown in Table 1.

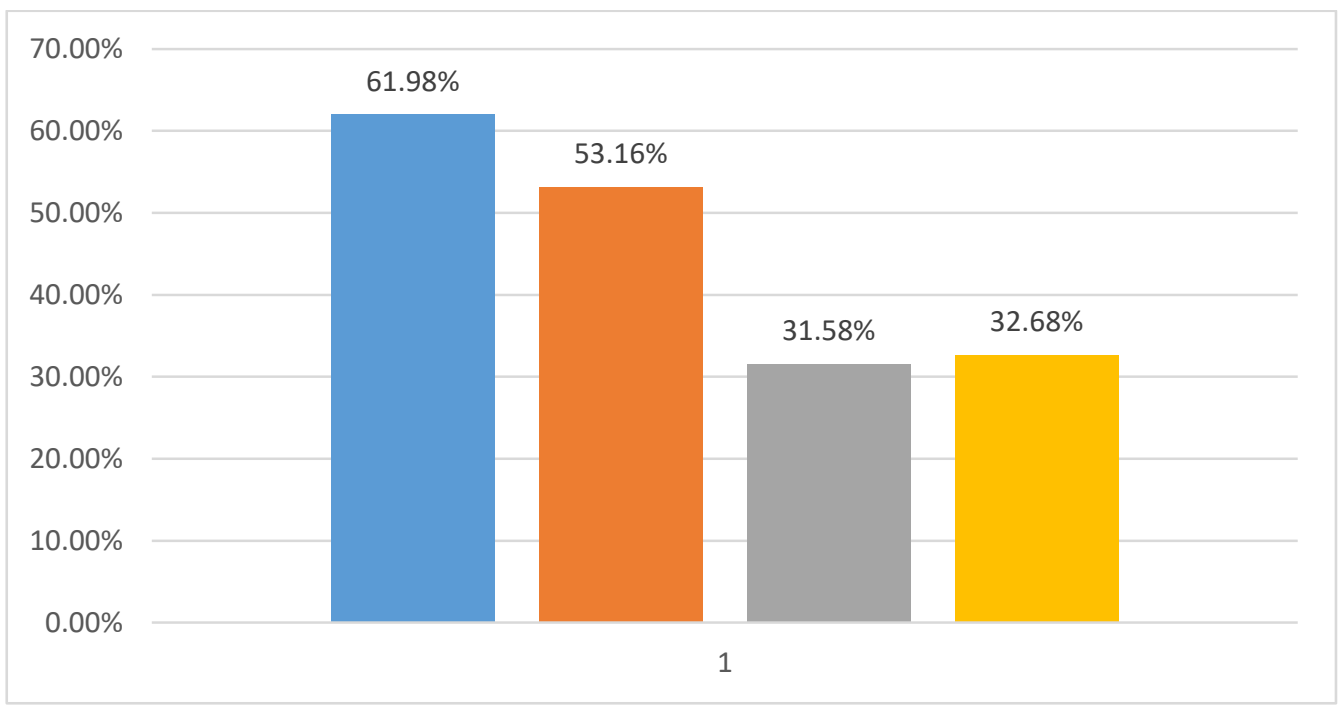

Figure 1. Student Knowledge Level Data on natural disaster mitigation

Based on the data obtained in the field, the answers from the respondents were then analyzed based on the students' knowledge. The analysis results are then tabulated to show the students' mitigation knowledge points which are the subject of this study. Analysis of the results of the percentage gain using the reference from the score of Table 2. Categories of Students' Knowledge Levels in the data analysis section.

Table 2. Student Knowledge Level Data on natural disaster mitigation

\begin{tabular}{lcc}
\hline Questions & Know & $\begin{array}{c}\text { Don't } \\
\text { Know }\end{array}$ \\
\hline Knowledge & 100,0 & 0 \\
Knowing the causes of flooding & 89,5 & 10,5 \\
Knowing the causes of landslides & 78,9 & 21,1 \\
Knowing the causes of forest fires & 68,4 & 31,6 \\
Knowing the losses caused by flooding & 63,2 & 36,8 \\
Knowing the losses caused by landslides & 73,7 & 26,3 \\
Knowing the losses caused by forest fires & 71,1 & 28,9 \\
Knowing the classification of floods, fires, and landslides that occurred in the area around & & \\
as a disaster & 39,5 & 60,5 \\
Getting information about areas or areas from the government regarding areas prone to & 68,4 & 31,6 \\
flooding. Knowing what to do in the event of a flood & 47,4 & 52,6 \\
Knowing what to do in the event of a landslide & 65,8 & 34,2 \\
Knowing what to do in the event of a forest fire & 81,6 & 18,4 \\
Knowing how to prevent flooding & 47,4 & 52,6 \\
Knowing how to prevent landslides & 34,2 & 65,8 \\
Knowing how to prevent forest fires & 5,3 & 94,7 \\
Knowing about natural disaster mitigation & 76,3 & 23,7 \\
Knowing lessons about flooding in schools & 68,4 & 31,6 \\
Learn lessons about forest fires in schools & \\
Knowing lessons about landslides at school &
\end{tabular}




\begin{tabular}{|c|c|c|}
\hline Questions & Know & $\begin{array}{l}\text { Don't } \\
\text { Know }\end{array}$ \\
\hline $\begin{array}{l}\text { Knowing what the government has done to deal with floods, landslides, and forest fires } \\
\text { Emergency response planning }\end{array}$ & 60,5 & 39,5 \\
\hline Knowing the action of contacting the family in case of flooding & 28,9 & 71,1 \\
\hline Knowing the action of contacting the family in the event of a forest fire & 73,7 & 26,3 \\
\hline Knowing the action of contacting the family in the event of a landslide & 52,6 & 47,4 \\
\hline Knowing the action of saving favorite items such as toys during a flood & 57,9 & 42,1 \\
\hline Knowing the action has a means of communication to use in an emergency & 34,2 & 65,8 \\
\hline Knowing self-rescue training when a disaster occurs & 47,4 & 52,6 \\
\hline $\begin{array}{l}\text { Disaster warning } \\
\text { Knowing the school bell can be used as a disaster warning system }\end{array}$ & 18,4 & 81.6 \\
\hline $\begin{array}{l}\text { Knowing the action, if there is a notification of a flood, fire, landslide, you have to scream } \\
\text { and cry } \\
\text { Mobilization of resources }\end{array}$ & 44,7 & 55,3 \\
\hline Knowing that taking part in a disaster simulation event is a tedious activity & 21,1 & 78,9 \\
\hline Understand how to reduce the risk of natural disasters & 18,4 & 81,6 \\
\hline $\begin{array}{l}\text { Knowing reading books/textbooks following games that contain lessons about how to deal } \\
\text { with floods, landslides, and forest fires }\end{array}$ & 68,4 & 31,6 \\
\hline Knowing the existence of local knowledge or wisdom related to natural disasters & 44,7 & 55,3 \\
\hline Knowing about natural disasters that have occurred in your area in the past & 21,1 & 78,9 \\
\hline Knowing the feelings of loss of life or material loss caused by natural disasters & 47,4 & 52,6 \\
\hline $\begin{array}{l}\text { Knowing that government actions in your area have/have made risk reduction efforts to } \\
\text { reduce the impact of natural disasters }\end{array}$ & 2,6 & 97,4 \\
\hline $\begin{array}{l}\text { Knowing the vital action to talk or discuss how to save yourself and your family in the } \\
\text { event of a disaster }\end{array}$ & 15,8 & 84,2 \\
\hline Knowing preparedness equipment/facilities and disaster mitigation in your area & 26,3 & 73,7 \\
\hline $\begin{array}{l}\text { Know what facility actions can be used to reach a safe place in the event of a natural } \\
\text { disaster }\end{array}$ & 13,2 & 86,8 \\
\hline Knowing how to save yourself & 55,3 & 44,7 \\
\hline Knowing safe evacuation routes (road routes) in the event of a disaster & 57,9 & 42,1 \\
\hline
\end{tabular}

First Aspect: Knowledge. All students knew the causes of flooding; they also answered what caused floods: littering, deforested forests or logging forests carelessly, clogging of water gutters. $89 \%$ of students also knew the causes of landslides. One of them was soil depletion, and $81 \%$ of students knew the causes of forest fires: reckless burning, uncontrolled human activity, and carelessly burning forests. $86 \%$ of students learn the losses caused by floodings, such as damage to their homes, economic losses, difficulty getting clean water, obstructed community activities, and casualties. 92\% of students knew about the losses caused by forest fires; for example, forests were deforested, and animals had no shelter or damage to animal habitats. Based on all information regarding natural disasters in floods, landslides, and forest fires, $55 \%$ of students get information about areas or areas from the government regarding flood-prone areas/areas. Students if do not know what to do in the event of a landslide disaster. This is evidenced by $58 \%$ of students claiming they do not know what to do if a landslide occurs, besides that, $55 \%$ of students learn how to prevent landslides, namely by doing reforestation, $34 \%$ of students know how to prevent forest fires, for example by not lighting fires carelessly, especially on dry trees and during the dry season. $7 \%$ of students know about natural disaster mitigation, $28 \%$ of students learn the efforts made by the government to cope with floods, landslides, and forest fires, for example, by carrying out reforestation.

Second Aspect: Emergency response planning. $28.9 \%$ of students would contact their families when a natural disaster occurred; however, none of the students have ever participated in a rescue simulation. Third Aspect: Disaster warning. $18 \%$ of students stated that the school bell could be a warning for natural disasters, and $44 \%$ would scream and cry if a natural disaster occurred. Fourth Aspect: Mobilization of resources. $45 \%$ of students have seen some reading books/textbooks following games containing teaching material on dealing with floods, landslides, and forest fires. $44 \%$ of students know local knowledge or wisdom related to natural disasters, $44 \%$ of students learn all of past natural disasters that occurred or happened in the student area. $21 \%$ of students experienced relative loss or material loss due to natural disasters. $47 \%$ of students knew any government efforts to reduce natural disaster impacts. $2.6 \%$ of students spoke or discussed how to save themselves and their families when a disaster occurred, $15 \%$ of students saw disaster 
preparedness and mitigation equipments/facilities in the area, such as boats or jukung, which are local means of transportation in river areas. $26 \%$ of students know the facilities used for evacuation to safe places, such as flood disasters, such as boats or jukung. $13 \%$ of students learn how to save themselves in the event of a disaster. For example, in a flood disaster, they can protect themselves by looking for a high area; $57 \%$ have an evacuation route (save route).

\section{Discussion}

The findings of this research support the value of mitigation knowledge in wetland student schools in South Kalimantan. Although the relevant agencies (namely, organizations working in the mitigation sector) have demonstrated the concept of disaster mitigation and education (Asep, 2012), students have a large gap between knowledge of mitigation and its achievement. Students are still puzzled in the matter of disaster adaptation and its risk. Only one result satisfies students with knowledge of disaster status. Most students think that disaster knowledge is fundamental, but only a few students know about disaster adaptation procedures. The analysis shows that most students have moderate knowledge about disasters and the students lack mitigation methods. Although $61 \%$ of the students questioned were aware of disasters, their opinions on disaster adaptation and behavior were somewhat surprising. They do not consider that disaster preparedness, and adaptation behavior is essential tools for mitigation.

The limitation of this research is the student's mitigation analysis methodology which is used only based on the percentage of students' knowledge about mitigation. This knowledge percentage is used to describe the condition of students' current mitigation knowledge. Therefore, further/more in-depth descriptions of students' mitigation knowledge were not provided/not found because this research was carried out precisely. Aims to get an overview of student mitigation in wetlands in South Kalimantan. The number of samples used in this study only represents respondents in wetlands in the Kalimantan area. Therefore, the main findings of this study are not suitable for describing the current disaster education system for regions outside the wetland areas in South Kalimantan. The results of the recent research are aimed at encouraging relevant agencies that have been working in the disaster education sector in South Kalimantan in particular, and in the Indonesian region, in general, to make further modifications in their programs as this type of independent research demonstrates the status of mitigation knowledge among school students are still common.

A study conducted by LIPI in 2006 showed that the readiness of the school community against earthquakes and tsunamis anticipation is poor (Asep, 2012). This is very unfortunate because students are part of the community most vulnerable to natural disasters. This causes the lack of experience in dealing with disasters to become a significant factor. Disaster knowledge in dealing with disasters included understanding has preparedness in facing disasters like being almost ready (Khoirunisa, 2016). Lack of knowledge on disasters will increase the vulnerability of the community. This fact shows that community knowledge of disaster mitigation needs to be improved. Therefore training activities for elementary school teachers such as those carried out in Long Pujungan District, Malinau District, shows that $84 \%$ of teacher training is very helpful in implementing teacher improvement because $88 \%$ of participants gain additional knowledge. And skills (Annisa, 2016) so that mitigation as one of the main ingredients of training needs to be improved. Another alternative approach is science learning which involves the inquiry process and engineering design because it can build skills and readiness in STEM learning which is currently the government's attention (Permanasari, 2021). In addition, there is also the STECS Model, which strongly supports Environmental Critical Thinking Skills (Purnami, 2021). It is also necessary to remember the spread of the Covid-19 virus, which has led to the emergence of technological innovations in learning which have led to new learning styles (Pratama, 2020).

The National Strategy for Disaster Risk Management announced in 2020-2024 by BNPB (National Agency for Disaster Management) in the National Disaster Management Plan 2020-2024 shows that the level of disaster in Indonesia is classified as medium and high where there are 257 areas classified as a medium category. Two hundred fifty-seven different areas are belonging to the high class. The South Kalimantan region is classified as a high disaster area category (BNPB, 2020). Even so, mitigation education has not been included informal education in the form that mitigation is not fully included in the formal curriculum at all school levels or through universities, which can be seen from the competencies given to students. Therefore, BNPB provides recommendations for strategic activities to develop and modify policies on education and implement them in such a way as to make schools an essential center for dissemination (BNPB, 2020)

The National Strategy for Disaster Risk Management announced for 2020-2024 by BNPB (National Disaster Management Agency) has shown that the level of disasters in Indonesia is moderate and high. However, in the South Kalimantan region, it is tall (BNPB, 2020). Mitigation education has not been included 
in formal education; mitigation is not fully included in the standard curriculum at all school levels or through universities. Therefore, BNPB provides recommendations for strategic activities to develop and modify policies on education and implement them in such a way as to make schools an important center for disseminating knowledge about mitigation issues (BNPB, 2020).

Disaster management framework in the role of education, school disaster education to form a culture of disasters. However, the findings of this independent study are due to insufficient initiatives taken for education in South Kalimantan. The main challenge for mitigation in school communities in a country like Indonesia is implementing implementation, especially at the individual level. The role of disaster education is to provide knowledge and information to students and take mitigation actions. To achieve these goals, school students can help to acquire a basic understanding of disasters, preparedness behavior, program awareness, adaptation processes, and risk perception techniques. To improve disaster management, more appropriate information should be disseminated to school students. Extra-curricular activities and disaster management campaigns can provide an independent educational environment for students. Likewise, teachers can also prioritize topics related to the disaster in the curriculum. It is time for teachers to think about disaster management to provide information through lectures because pedagogy always has a crucial role in transmitting knowledge and learning competencies. In addition, the community can determine in school disaster education, and students can participate in school activities and community organizations. This activity can help students to build good relationships with the community.

\section{CONCLUSIONS}

It is a common fact that to develop an understanding of mitigation, the government alone cannot take all mitigation actions in the community. Therefore, disaster education is limited to school students and must also be promoted to families and communities, which is very important for elaborating mitigation knowledge, ultimately contributing to building a disaster-safe society in Indonesia. In addition, it is necessary to carry out further research on the development of teaching materials that can increase students' knowledge about mitigating natural disasters in wetland areas.

\section{REFERENCES}

Annisa, M., \& Hamid, H. (2017). Pengembangan profesionalisme guru melalui pelatihan penyusunan karya tulis ilmiah di wilayah pedalaman. Widya Laksana, 5(2), 81-84.

Arai, Y., Oktoriana, S., Suharyani, A., \& Inoue, M. (2021). How Can We Mitigate Power Imbalances in Collaborative Environmental Governance? Examining the Role of the Village Facilitation Team Approach Observed in West Kalimantan, Indonesia. Sustainability, 13(7), 3972.

Asep, K. T. (2012). Panduan Monitoring dan Evaluasi Sekolah Siaga Bencana. LIPI Press, 15(3); 396-413.

Austin, K. G., Kasibhatla, P. S., Urban, D. L., Stolle, F., \& Vincent, J. (2015). Reconciling oil palm expansion and climate change mitigation in Kalimantan, Indonesia. PLoS One, 10(5), e0127963.

BNPB. (2020). https://bpba.acehprov.go.id/uploads/. Retrieved from https://bpba.acehprov.go.id: https://bpba.ace hprov.go.id/uploads/Renas_PB_2020-2024_(book_layout).pdf

BNPB. (2021). https://bnpb.go.id. Retrieved from https://bnpb.go.id: https://bnpb.go.id/potensi-ancamanbencana

CRED. (2017). Centre for Research on the Epidemiology of Disasters. CRED, CredCrunch\#50.

Hadi, A., Jumadi, O., Inubushi, K., \& Yagi, K. (2008). Mitigation options for $\mathrm{N} 2 \mathrm{O}$ emission from a corn field in Kalimantan, Indonesia. Soil science and plant nutrition, 54(4), 644-649.

Jairina, S. N. I., Handoyo, B., \& Astina, I. K. (2020). Pengaruh Model Pembelajaran Problem Based Learning Terhadap Kemampuan Pemecahan Masalah Mitigasi Bencana. Jurnal Pendidikan: Teori, Penelitian, dan Pengembangan, 5(2), 225-228.

Jati, D. R. (2021). Lebih dari Dua Puluh Ribu Jiwa Terdampak Banjir di Kalimantan Selatan. Retrieved from bnpb.go.id: https://bnpb.go.id/berita/lebih-dari-dua-puluh-ribu-jiwa-terdampak-banjir-di-kalimantanselatan

Khoirunisa, N. (2016). Disaster knowledge of student for disaster preparedness. In Proceeding on The First International Conference on Child-Friendly Education (pp. 11-12). 
Kurniawan, M. R. (2019). Pusat Penanggulangan Bencana Daerah Provinsi Kalimantan Barat. Jurnal Online Mahasiswa S1 Arsitektur UNTAN, 7(1).

Lounela, A. (2020). Contested values and climate change mitigation in Central Kalimantan, Indonesia. Social Anthropology, 28(4), 862-880.

Murdiyarso, D., Kauffman, J. B., \& Verchot, L. V. (2013). Climate change mitigation strategies should include tropical wetlands. Carbon Management, 4(5), 491-499.

Nyong, A., Adesina, F., \& Elasha, B. O. (2007). The value of indigenous knowledge in climate change mitigation and adaptation strategies in the African Sahel. Mitigation and Adaptation strategies for global Change, 12(5), 787-797.

Permanasari, A., Rubini, B., \& Nugroho, O. F. (2021). STEM Education in Indonesia: Science Teachers' and Students' Perspectives. Journal of Innovation in Educational and Cultural Research, 2(1), 7-16.

Pratama, H., Azman, M. N. A., Kassymova, G. K., \& Duisenbayeva, S. S. (2020). The Trend in using online meeting applications for learning during the period of pandemic COVID-19: A literature review. Journal of Innovation in Educational and Cultural Research, 1(2), 58-68.

Purnami, W., Sarwanto, S., Suranto, S., Suyanti, R. D., \& Mocerino, M. (2021). Investigation of Science Technology Ecocultural Society (STECS) Model to Enhance Eco Critical Thinking Skills. Journal of Innovation in Educational and Cultural Research, 2(2), 77-85.

Rahma, A. (2018). Implementasi program pengurangan risiko bencana (PRB) melalui pendidikan formal. Jurnal VARIDIKA, 30(1), 1-11.

Ronan, K. R., Crellin, K., \& Johnston, D. (2010). Correlates of hazards education for youth: a replication study. Natural hazards, 53(3), 503-526.

Rosyidie, A. (2013). Banjir: fakta dan dampaknya, serta pengaruh dari perubahan guna lahan. Jurnal Perencanaan Wilayah dan Kota, 24(3), 241-249.

Sadewo, M. G., Windarto, A. P., \& Wanto, A. (2018). Penerapan Algoritma Clustering Dalam Mengelompokkan Banyaknya Desa/Kelurahan Menurut Upaya Antisipasi/Mitigasi Bencana Alam Menurut Provinsi Dengan K-Means. KOMIK (Konferensi Nasional Teknologi Informasi dan Komputer), 2(1).

Salminah, M., \& Alviya, I. (2019). Efektivitas Kebijakan Pengelolaan Mangrove Untuk Mendukung Mitigasi Perubahan Iklim Di Provinsi Kalimantan Timur. Jurnal Analisis Kebijakan Kehutanan, 16(1), 11-29.

Sudrajat, A. S. E., \& Subekti, S. (2019). Pengelolaan ekosistem gambut sebagai upaya mitigasi perubahan iklim di Provinsi Kalimantan Selatan. Jurnal Planologi, 16(2), 219-237.

Surahman, A., Shivakoti, G. P., \& Soni, P. (2019). Climate change mitigation through sustainable degraded peatlands management in Central Kalimantan, Indonesia. International Journal of the Commons, 13(2).

Tuladhar, G., Yatabe, R., Dahal, R. K., \& Bhandary, N. P. (2014). Knowledge of disaster risk reduction among school students in Nepal. Geomatics, Natural Hazards and Risk, 5(3), 190-207.

Van der Laan, C., Wicke, B., Verweij, P. A., \& Faaij, A. P. (2017). Mitigation of unwanted direct and indirect land-use change-an integrated approach illustrated for palm oil, pulpwood, rubber and rice production in North and East Kalimantan, Indonesia. Gcb Bioenergy, 9(2), 429-444.

Wahyuningtyas, A., \& Pratomo, R. A. (2015). Identifikasi Potensi Multi-Bencana Di Kabupaten Landak Kalimantan Barat. Geoplanning: Journal of Geomatics and Planning, 2(1), 10-21.

Wedyawati, N., Lisa, Y., \& Selimayati, S. (2017). Pengaruh Model Pembelajaran IPA Terintegrasi Mitigasi Bencana Terhadap Hasil Belajar. Edukasi: Jurnal Pendidikan, 15(2), 261-273. 